\title{
Path Analysis on the Factors Affecting People's Behavior in HIV/AIDS Countermeasure on People Living with HIV/AIDS (PLWHA) in Solo Plus Peer Support Group, Surakarta
}

\author{
Kingkin Adita'), Argyo Demartoto²), Eti Poncorini Pamungkasari3) \\ ${ }^{1)}$ Masters Program in Public Heath, Sebelas Maret University, Surakarta \\ ${ }^{2)}$ Faculty of Social and Political Sciences, Sebelas Maret University, Surakarta \\ ${ }^{3)}$ Faculty of Medicine, Sebelas Maret University, Surakarta
}

\begin{abstract}
Background: HIV or Human Immunodeficiency Virus is a virus that infects white blood cells so the person's immunity declining thus causing it to become AIDS. HIV/AIDS countermeasure is far more effectively done by people living with HIV/AIDS (PLWHA) accompanied by good attitude and peer support, family, and health workers, Regional AIDS Countermeasure Commission, perceived behavioral control, and positive intention. The study aimed to analyze factors affecting the attitude in HIV/AIDS countermeasure on PLWHA in Solo Plus Peer Support Group (PSG) Surakarta with theory of planned behavior application.

Subjects and Methods: The study design was analytic observational with cross sectional study approach. The location of the study was Solo Plus Peer Support Group Surakarta. Time of study was from January-February 2017. There was a total of 100 PLWHA as the sample, and the study employed purposive sampling technique. The dependent variable was the attitude towards HIV/AIDS countermeasure. The independent variables were the attitude, peer, family, health workers, Regional AIDS Countermeasure Commission support, perceived behavioral control and their intention. The variables were measured with questionnaires. Data analysis technique used was path analysis.

Results: HIV/AIDS countermeasure attitude affected by intention( $b=0.27 ; \mathrm{SE}=0.10 ; \mathrm{p}=0.012)$, peer support $(b=0.26 ; \mathrm{SE}=0.14, \mathrm{p}=0.066)$, AIDS Countermeasure Commission support $(\mathrm{b}=0.10$; $\mathrm{SE}=0.10 ; \mathrm{p}=0.321)$, health workers support $(\mathrm{b}=0.25, \mathrm{SE}=0.14, \mathrm{p}=0.073)$ and perceived behavioral control $(b=0.23 ; \mathrm{SE}=0.13 ; \mathrm{p}=0.065)$. Intention affected by attitude $(\mathrm{b}=0.28 ; \mathrm{SE}=0.15$; $\mathrm{p}=0.059)$, peer support $(\mathrm{b}=0.29 ; \mathrm{SE}=0.13 ; \mathrm{p}=0.026)$, family support $(\mathrm{b}=0.16 ; \mathrm{SE}=0.09, \mathrm{p}=$ $0.090)$ and perceived behavioral control $(\mathrm{b}=0.21 ; \mathrm{SE}=0.11 ; \mathrm{p}=0.090)$.

Conclusion: HIV/ AIDS countermeasure behavior was very much affected by the intention, peer support, AIDS Countermeasure Commission support, health worker support, and perceived behavioral control. Their intention was affected by attitude, peer support, family support, and perceived behavioral control.
\end{abstract}

Keywords: HIV, PLWHA, TPB, countermeasure.

\section{Correspondence:}

Kingkin Adita. Masters Program in Public Heath, Sebelas Maret University, Surakarta. Email: kingkin_adita@gmail.com. Mobile: 085726389133.

\footnotetext{
BACKGROUND

HIV or Human Immunodeficiency Virus is a virus attacking/infecting the white blood cells causing the declining in the patient's immunity and afterward as soon as a series of diseases appear then it is called AIDS or Acquired Immune Deficiency Syndrome
}

which is the last stadium manifestation of HIV infection (Kemenkes, 2014; Kresno, 2010). HIV/AIDS cases keep on escalating and have become global health problem and is now a serious worldwide epidemic (Ignatavicius and Workman, 2010). The strategy, and policies in counter-measuring 
Journal of Health Promotion and Behavior (2017), 2(1): 41-54

https://doi.org/10.26911/thejhpb.2017.02.01.04

HIV/ AIDS has already been set up from global to regencies/ cities level with the objective is to eliminate new HIV infection, HIV-related deaths, as well as eliminating HIV discrimination worldwide (WHO, 2016).

One of HIV/AIDS countermeasure according to Buse et al., (2016) is to allow Greater Involvement of People Living with AIDS/ GIPA. GIPA is very important for epidemic countermeasure because it gives ethical and more effective as well as more responsive service to support, empower, and lift up the spirit and self esteem of those with HIV/ AIDS. It also helps to reduce the stigma and discrimination from others, strengthen the organization or activities by giving first person experience from PLWHA or affected by the disease (Spiritia, 2003). The most effective countermeasure itself actually comes from PLWHA, by referring to TPB (Theory of Planned Behavior) i.e.: attitude, subjective norm (peer, family, health worker, Regional AIDS Countermeasure Commission support), perceived behavioral control, and intention.

TPB is an individual intention prediction in specific time and place. Individual behavior is driven by behavioral intention, where behavioral intentions are a function of three individual determinants of attitudes toward behavior, subjective norms, and behavioral control. The attitude is a belief that one has towards the consequences of the committed behavior. It may have positive or negative assessment ( $\mathrm{Aj}$ zen, 1991). The subjective norm is one's perception towards social pressure in their environment. The more an individual perceived that a social reference recommended a certain kind of behavior, the more the individual felt social pressure to behave accordingly, whereas if the individual perceived that the social reference recommended not to do a certain behavior, thus the individual would feel social pressure to not behave accordingly (Fishbein dan Ajzen, 1975). Perceived behavioral control is an individual perception regarding the ease or difficulty in committing a certain behavior. It is a personal belief towards supporting or obstacle factor in committing certain behavior.

\section{SUBJECT AND METHOD}

The design of this study was observational analitic with cross sectional approach. The location for the study was Solo Plus Peer Support Group, Surakarta. The time of the study was January-February 2017. The population of PLWHA in Solo Raya was 2,068. The study subject as many as 100 PLWHA was chosen with purposive sampling technique.

The dependent variables was the countermeasure attitude against HIV/ AIDS, independent variables were attitude, supports from peer, family, health worker, and KPA, perceived behavioral control, and intention. The instrument used for the study was questionnaires. The measuring scale was continuous. Data analysis was using path analysis.

Operational Definitions of intention was motivation, willingness, or determination of the PLWHA in deciding to take part in HIV/ AIDS countermeasure behavior. The intention was determined by the positive or negative attitude of PWLHA towards HIV/AIDS countermeasure behavior. Attitude was determined by the confidence or response of PLWHA's feeling in the form of negative or positive behavior on the HIV/ AIDS countermeasure action done.

Peer support was the support given by Solo Plus Peer Support Group, Surakarta (members and management) for PLWHA that became members of Solo Plus Peer Support Group (PSG). Family support was 
the support given to PLWHA by their family members (father/ mother/ husband/ wife/ children/ siblings) biologically/ not, living under the same roof/ not. Support from health practitioner was the support given to PLWHA by health worker who knew their HIV/ AIDS status. Regional AIDS Countermeasure Commission support was the support given by Regional AIDS Countermeasure Commission to PLWHA.

The mentioned support might come in material support, i.e.: provision of facilities and making it easier to achieve the goals by providing financial support, food, medicine, vehicles, giving opportunities, leeway, time, and services. Emotional support is the support that has something to do with emotion, affection, and expression. It might come in the form of spirit, warmth, concern, thoughtfulness, love, emotion, expression, empathy, calmness, sense of belonging and be loved.

Appreciation support is a positive expression to PLWHA, in the form of information that PWLHA is appreciated and accepted, acknowledged, owned, and loved by others, positively appreciated, forwardly pushed, and acknowledged for the efforts done and given positive feedback on their result or achievement. Social integrity support is a feeling by PLWHA that they are part of a group. Informative support is giving the information needed by PLWHA, for example health education, instructions, advice, and feedback.

Perceived behavioral control is PLWHA subjective assumption about the ease or difficulty/ supporting factor or barrier (internal and external) to commit HIV/AIDS countermeasure behavior. HIV/ AIDS countermeasure behavior is PLWHA involvement in HIV/AIDS countermeasure based on GIPA's involvement pyramid from UNAIDS which consists of target listener, supporter, speaker, implementer, experts, and decision makers. The involvement as per Spiritia is also for decision making, countermeasure/treatment, PSG organizers, PSG leaders, PSG members, and personal involvement. All variables were measure using likert scale.

Face validity had previously verified by a language expert Ms. Heny Setya Purwandari, S.Pd and the content validity done by Ms. Emi Zulaikha as the head of PSG. Reliability technical test with Alpha Cronbach was done on 20 PLWHA in PSG Solo Plus.

Univariat data analysis described using parameter $\mathrm{n}$, mean, $\mathrm{SD}$, minimum and maximum. Bivariat analysis using correlation Pearson product moment. Multivariat analysis using path analysis.

\section{RESULT}

\section{Research Subject Characteristic}

Based on Table 1, it was known that most of the subject of the study as 31-40 years old (37\%), male as many as 66 subject (66\%), finished senior high school/equivalent (52\%), working in private sector (75\%), married (55\%) and knew their HIV/ AIDS for $>6$ months as many as 60 (60\%). 
Table 1. The characteristics of the subject based on age, gender, educational background, marital status and how long they knew their PLWHA status

\begin{tabular}{lcc}
\hline & Classification & n \\
\hline Age & 34 & 34 \\
20-30 years old & 37 & 37 \\
31-40 years old & 21 & 21 \\
$41-50$ years old & 5 & 5 \\
$51-60$ years old & 3 & 3 \\
61-70 years old & & 66 \\
Gender & 66 & 34 \\
Male & 34 & \\
Female & & 3 \\
Education & 3 & 10 \\
Did not finish Primary School & 10 & 24 \\
Primary School/ equivalent & 24 & 52 \\
Secondary School/ equivalent & 52 & 4 \\
Senior High School/ equivalent & 4 & 11 \\
Associate Degree & 11 & \\
Bachelor's Degree & & 23 \\
Occupation & 23 & 75 \\
Housewife & 75 & 2 \\
Private & 2 & \\
University Students & & 50 \\
Marital Status & 55 & 33 \\
Married & 33 & \\
Unmarried & 12 & \\
Divorced & & \\
Length of knowing PLWHA status & 90 & \\
more than 6 months & 10 & \\
Less than 6 months & & \\
\hline
\end{tabular}

\section{Univariat Analysis}

Table 2 showed that the standard deviation was around 3.98 to 6.95 , the differences happened on each variables was relatively large and this meant that the subjects answered differently (heterogenize).

Table 2. Description of the Research variables

\begin{tabular}{lcccc}
\hline \multicolumn{1}{c}{ Variables } & Mean & SD & Min & Max \\
\hline HIV/ AIDS Countermeasure behavior & 38.11 & 6.95 & 24 & 52 \\
Intention & 39.00 & 6.06 & 22 & 50 \\
attitude & 37.00 & 3.98 & 28 & 47 \\
Peer support & 36.41 & 4.48 & 16 & 40 \\
Family support & 32.72 & 6.25 & 10 & 40 \\
Health worker support & 34.33 & 4.65 & 13 & 40 \\
AIDS Countermeasure Commission & 30.24 & 6.59 & 14 & 40 \\
support & & & & \\
perceived behavioral control & 34.89 & 5.09 & 23 & 45 \\
\hline
\end{tabular}


Adita et al./ Path Analysis on the Factors Affecting People's Behavior in HIV/AIDS Countermeasure

3. Bivariate Analysis

Table 3. Pearson product moment test in terms of the effect on the attitude, peer, family, health worker and Regional AIDS Countermeasure Commission support, perceived behavioral control, and intention HIV/AIDS countermeasure behavior.

\begin{tabular}{lcc}
\hline \multicolumn{1}{c}{ Independent Variables } & $\mathbf{r}$ & $\mathbf{p}$ \\
\hline Attitude & 0.23 & 0.021 \\
Peer support & 0.28 & 0.005 \\
Family support & 0.24 & 0.018 \\
health worker support & 0.31 & 0.001 \\
Regional AIDS Countermeasure Commission support & 0.22 & 0.025 \\
Perceived behavioral control & 0.27 & 0.007 \\
Intention & 0.36 & $<0.001$ \\
\hline
\end{tabular}

Table 3 provided the result of the correlation test using Pearson's product moment in relation to the HIV/AIDS countermeasure behavior, gathered that the $\mathrm{r}$ value was 0.23 with $\mathrm{p}$ value 0.021 . This showed that there was a weak relation and statistically significant between attitude and HIV/AIDS countermeasure behavior.

Pearson product moment correlation test regarding family support with HIV/ AIDS countermeasure behaviour was gathered with $\mathrm{r}$ value 0.24 and $\mathrm{p}$ value 0.018 . This showed that there was a weak relation and statistically significant between family support and HIV/AIDS countermeasure behavior. Pearson product moment correlation test about the relations between health worker and HIV/AIDS countermeasure behavior showed that there was $r$ value 0.31 and $p$ value 0.001 . This showed a moderate and statistically significant relation between support from health worker and HIV/AIDS countermeasure behavior.

Pearson product moment correlation test result regarding support from Regional AIDS Countermeasure Commission and HIV/AIDS countermeasure behavior gathered that $\mathrm{r}$ value was 0.22 with $\mathrm{p}$ value 0.025. This showed that there was a weak and statistically significant relationship between support from Regional AIDS Countermeasure Commission and HIV/ AIDS countermeasure behavior. Pearson product moment correlation test result between perceived behavioral control and HIV/ AIDS countermeasure behavior gathered $r$ value 0.27 and $p$ value 0.007 . This showed that there was a weak and statistically significant relationship between perceived behavioral control and HIV/ AIDS countermeasure behavior.

Pearson product moment correlation test regarding the relationship between intention and HIV/AIDS countermeasure behavior, it was gathered $r$ value 0.36 with $\mathrm{p}<0.001$. This showed that there was a moderate relationship and statistically significant between intention and HIV/ AIDS countermeasure behavior

\section{Path Analysis}

Picture 1 showed the structural model after the estimation using IBM SPSS AMOS 22, thus gathered the value as per the said picture. The indicators showed the path analysis model conformity as per table 4 that also showed the existence of goodness of fit measure that gathered the value fit index CMIN as much as 5.693 with $\mathrm{p}=$ $0.223>0.05, \mathrm{GFI}=0.986>0.90, \mathrm{NFI}=$ $0.947>0.90, \mathrm{CFI}=0.978>0.90, \mathrm{RMSEA}=$ $0.065>0.08$. Meaning, the empirical model fit the set criteria and confirmed fitting the empirical data. 


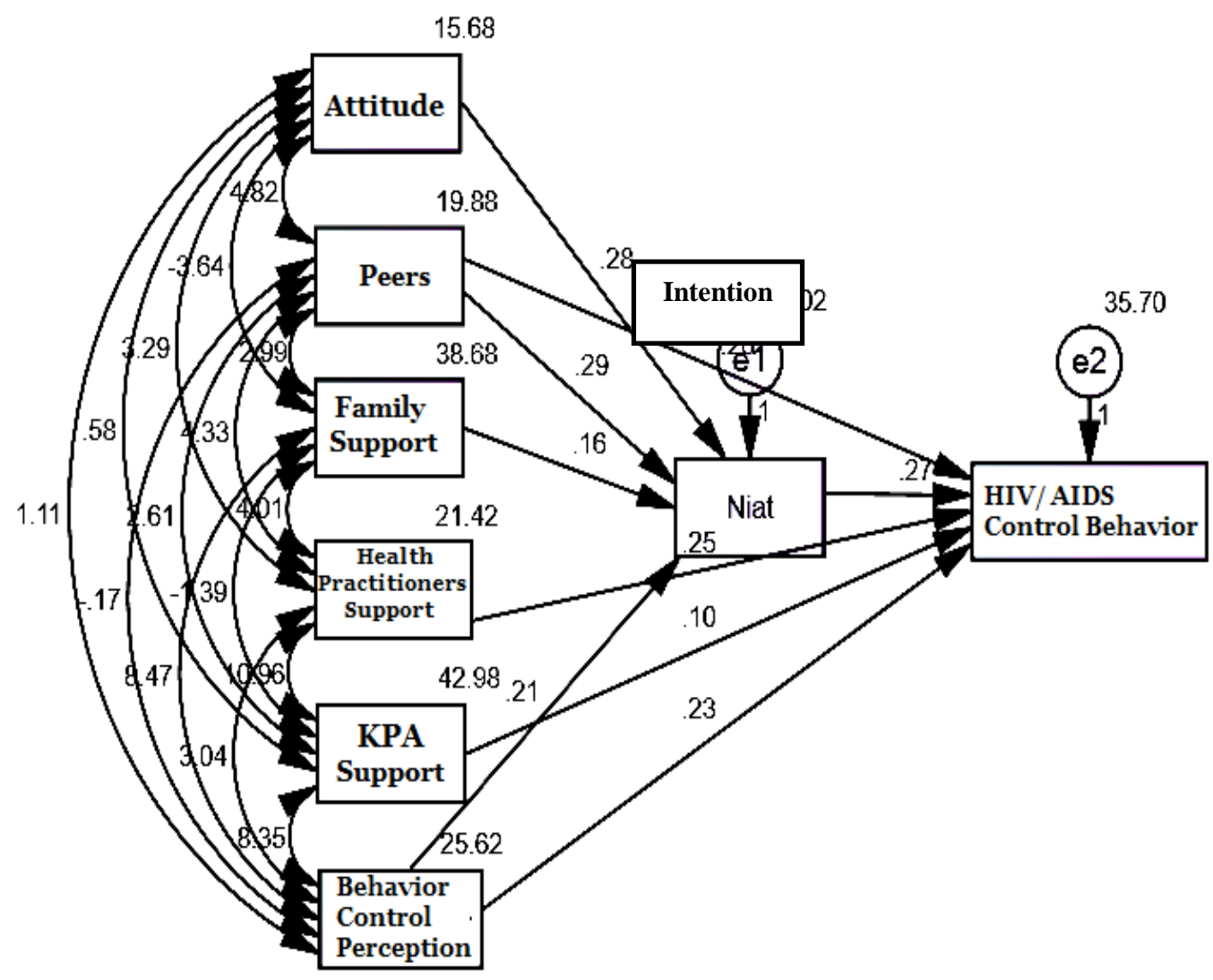

Picture 1. Structural Model in HIV/ AIDS countermeasure with unstandardized solution

Based on the study, it was known HIV/ AIDS countermeasure behavior was supported by intention, peer support, family support, KPA support, health worker support, and behaviour perception control.

a. Every one unit increase in intention will improve behavior as many as 0.27 unit $(\mathrm{b}=0.27, \mathrm{SE}=0.10, \mathrm{p}=0.012$ ).

b. Every one unit increase in peer support will improve behavior as many as 0.26 unit $(\mathrm{b}=0.26 ; \mathrm{SE}=0.14, \mathrm{p}=0.066)$.

c. Every one unit increase in KPA support, will improve behavior as many as 0.10 unit $(b=0.10 ; \mathrm{SE}=0.10 ; \mathrm{p}=0.321)$.

d. Every one unit increase in health worker support will improve behavior as many as 0.25 unit $(b=0.25, \mathrm{SE}=0.14, \mathrm{p}=$ 0.073).
Intention was affected by attitude, peer and family support, and perceived behavioural control.

a. Every one unit increase in will increase the intention as many as 0.28 unit $(b=$ 0.28; $\mathrm{SE}=0.15 ; \mathrm{p}=0.059$ ).

b. Every one unit increase in peer support will improve the intention as many as 0.29 unit $(b=0.29 ; \mathrm{SE}=0.13 ; \mathrm{p}=0.026)$.

c. Every one unit increase in family support will increase the intention as many as 0.16 unit $(b=0.16 ; \mathrm{SE}=0.09, \mathrm{p}=$ 0.090).

d. Every one unit increase in perceived behavioral control will improve the intention as many as 0.21 unit $(b=0.21$; $\mathrm{SE}=0.11 ; \mathrm{p}=0.090)$. 
Adita et al./ Path Analysis on the Factors Affecting People’s Behavior in HIV/AIDS Countermeasure

Tabel 4. Path Analysis result on the factor affecting HIV/AIDS countermeasure behavior

\begin{tabular}{|c|c|c|c|c|c|c|c|}
\hline \multicolumn{3}{|c|}{ Independent Variables } & Dependent Variables & $\mathbf{b}^{*}$ & $\mathbf{S E}$ & $\mathbf{p}$ & $\boldsymbol{\beta}^{* *}$ \\
\hline \multicolumn{8}{|c|}{ Direct Effect } \\
\hline Behavior & & $\leftarrow$ & Perceived behavioral control & 0.23 & 0.13 & 0.065 & 0.17 \\
\hline Behavior & & $\leftarrow$ & KPA support & 0.10 & 0.10 & 0.321 & 0.09 \\
\hline Behavior & & $\leftarrow$ & Peer support & 0.26 & 0.14 & 0.066 & 0.17 \\
\hline Behavior & & $\leftarrow$ & Heath worker support & 0.25 & 0.14 & 0.073 & 0.17 \\
\hline Behavior & & $\leftarrow$ & Intention & 0.27 & 0.10 & 0.012 & 0.23 \\
\hline \multicolumn{8}{|c|}{ Indirect Effect } \\
\hline Intention & & $\leftarrow$ & Peer support & 0.29 & 0.13 & 0.026 & 0.21 \\
\hline Intention & & $\leftarrow$ & Attitude & 0.28 & 0.15 & 0.059 & 0.18 \\
\hline Intention & & $\leftarrow$ & Perceived behavioral control & 0.21 & 0.11 & 0.090 & 0.17 \\
\hline Intention & & $\leftarrow$ & Family support & 0.16 & 0.09 & 0.090 & 0.17 \\
\hline \multicolumn{8}{|c|}{$\mathrm{N}$ Observasi $=100$} \\
\hline \multicolumn{8}{|c|}{ Fit Model } \\
\hline CMIN & $=5.693$ & & & & & & \\
\hline GFI & $=0.986$ & & & & & & \\
\hline NFI & $=0.947$ & & & & & & \\
\hline CFI & $=0.978$ & & & & & & \\
\hline $\mathrm{p}$ & $=0.223$ & & & & & & \\
\hline
\end{tabular}

\section{DISCUSSION}

\section{The effect of intention towards HIV/ AIDS countermeasure}

Path analysis result on this study showed that there was a positive relation between intention and HIV/ AIDS countermeasure behavior and statistically significant. PLWHA had high intention in preventing HIV/AIDS. They wanted to keep on preventing further HIV/ AIDS infection to those who were still negatively HIV tested and also prevented HIV/ AIDS. PLWHA would also like to join peer group meeting every month so that it would benefit for other PLWHA and to those with negative HIV/ AIDS.

The main factor of TPB is intention. The intention becomes the willingness control. Intention is the function of the three deciding factors in an individual, i.e.: attitude, subjective norms, and behavioral control (Ajzen, 1991). Intention is a desire and determination to commit certain behaviour without any doubt (Priyoto, 2014). Intention according to Fishbein and
Ajzen (1975) is a component in every individual that referred to a desire to carry out a certain behavior. If an individual has an intention to carry out certain behaviour, thus the said individual would mostly likely carry out the intended behaviour and vice versa. The stronger the intention, the most likely the person would carry out the behaviour.

Merken et al., (2011) shows that the higher the level of one's intention to commit something, the higher the likeliness of the said person to carry out the behaviour. The same thing also mentioned by Smith et al., (2007) and Cooke et al., (2014) that intention affecting one's behaviour. A strong intention to carry out a behaviour will strengthen one to control one's behaviour in any situation. One's effort will be useless if it does not have strong intention (Rosita et al., 2012; Wismanto dan Sarwo, 2006). 


\section{The effect of attitude towards HIV/} AIDS countermeasure behavior

Path analysis result in the study showed that attitude had a positive and indirect relation toward HIV/AIDS countermeasure behavior even though it was statistically insignificant. Attitude is a belief one has towards the consequences of a committed behaviour. Such assessment could be positive or negative assesment (Fishbein dan Ajzen, 1975; Ajzen, 1991).

According to Azwar (2011) a positive attitude is not always or automatically materialized in the form of behavior. The relation between behavior and attitude is very much depended on certain situational factors, norms, role, group membership, culture, and others are dependency condition that could change the relation between attitude and behaviour. The study is supported by Fathimah (2014) finding that mentioned that one's positive attitude may not always result in good behavior.

Aisyah (2012) shows that there is not any significant relation between one's attitude and one's HIV/ AIDS countermeasure behavior. One may have positive attitude but it does not mean that one will have positive behaviour because it is very much dependent on different individual charasteristics. Every individual will have differences in learning experience, educational background, social status, even cultural background in their environment.

3. The effect of peer support towards HIV/ AIDS countermeasure behavior

Path analysis result in the study showed that peer support had direct and positive relation towards HIV/ AIDS countermeasure behavior even though it was statistically insignificant but peer support gave indirect and positive relation towards HIV/ AIDS countermeasure behavior and was statistically significant.
Peer support also affects PLWHA intention in carrying out HIV/AIDS countermeasure behavior (Thorhauge et al., 2016). Spiritia (2011) study shows that PLWHA that joins peer support group has better living quality compared to PLWHA who does not join any peer support group. Yuswanto (2015) shows that PSG gives positive impact on PLWHA quality of life.

Diatmi and Fridari (2014) study analysis shows that there is a positive relation between social support and quality of life of PLWHA. PSG gave information related to health services, emotional support, and accompaniment to PLWHA who has health problems. Monitoring their discipline in undergoing their medical therapies, especially ARV therapies. Providing limited financial assistance through their program Positive Fund. Providing information and knowledge regarding HIV and AIDS basic knowledge, how to open up to others about their medical status, ARV medication, and other science development that would help in improving PLWHA quality of life.

Thilakavathi et al., (2011) mentions that there is not any relation between peer support and HIV/AIDS countermeasure behavior. This caused by the lack of peer support for example informative support.

\section{The effect of family support towards HIV/ AIDS countermea- sure behavior}

Path analysis result on the study showed that family support had indirect and positive relation toward HIV/ AIDS countermeasure behavior, even though it was statistically insignificant. Family is a place to hang on to and it gives the biggest influence on PLWHA in dealing with different kinds of problems related to HIV/AIDS disease (Gustya et al., 2015).

This is also confirmed by Kusuma (2011) that family support is very much 
needed by PLWHA as the main support system so that it could help developing effective coping response to allow better adaption in dealing with stressor faced in connection to their disease physically, psychologically, and socially.

Tuapattinaja (2004) study shows that PLWHA needs a lot of emotional support from different social sources especially their family, PLWHA hopes that their family could accept, care, comfort, and surrounded by people that loves them. Instrumental support is also needed by PLWHA to carry out their function and role as PLWHA. Advices or information linked to health improvement is also needed by PLWHA as part of informational support. Families are expected to take active roles in improving the health of PLWHA.

A study from Kusuma (2011) shows that family support is the most meaningful relationship in the life of PLWHA. Kusuma (2011) finding is in accordance with this study that gathered the result that PLWHA got material, emotional, appreciation, and social integrity support. Such supports were well accepted by PLWHA but the informational support they got was not yet maximum.

\section{The effect of health worker to- wards HIV/ AIDS countermeasure behavior}

Path analysis result in the study showed that health worker support had direct and positive relations towards HIV countermeasure behavior, even though it was statistically insignificant. This was supported by the study done by Grimwood et al., (2012), that shows that supports from health worker will improve PLWHA health status.

Personal treatment done by oleh Johnson and Kanna (2004), as well as Joseph et al., (2012) by preparing food, housechores, administering medicines, needs availability assessment, altering com- munication behaviour towards their partner, domestic violence (Selke et al.,, 2010), inheritance, HIV education and counseling. These improve the quality of life, dignity, sense of belonging, and reducing stigma. TB directives and therapies, diarrhea, malaria, side effect education, opportunistic infections, social supports, increased revenue by doing some gardening, and making friendship improve the health of PLWHA (Rich et al., 2012 dan Simon et al., 2009).

Health worker play a role in visiting homes, delivering medicine, adherence counseling, giving feedbacks from the doctors on the patients' health status. The result attained is timely patient referral, lowering stigma, and improvement in relationship and family support, lessening workload, medical treatment access improvement, and improvement in communication with the patients (Alamo et al., 2012; Arem et al., 2011; dan Apondi et al., 2007).

Condom distribution, directives about PMTCT, HIV infection countermeasure education and opportunistic infection, and referral will improve the quality of life, improvement in ARV access and children born from HIV positive mothers has HIV negative. The assistance of the health worker in disclosing their status will help improving their confidence and lessening the myths around HIV and ART (Igumbor et al., 2011; Chang et al., 2010; Kipp et al., 2011; Kipp et al., 2012 and Zachariah et al., 2007).

Mwai et al., (2013) finds that material and service supports in the form of food, medicine, condom distribution, ART and cotrimoxale deliveries, laboratories samples management, accompaniment to the clinic, registering, measuring and checking vital signs, RT effect monitoring, HIV development monitoring, personal care in cleaning 
wounds and getting dressed, training and jobs support amd screening is very much needed by PLWHA.

\section{The effect of Regional AIDS Countermeasure Commission sup- port towards HIV/AIDS counter- measure behavior}

Path analysis result on the study showed that Regional AIDS Countermeasure Commission support had direct and positive relation towards HIV/AIDS countermeasure behavior, even though it was statistically insignificant. According to Regional AIDS Countermeasure Commission Surakarta (2016) and KPAN (2003) that KPA plays a role in giving supports in the form of exercising advocacy to the decision makers regarding health services and medicinal supplies; improving education and training for those involved in the care, treatment, and supports for PLWHA; counseling training and adding professional as well as volunteers including PLWHA in giving the care, quality treatment and supports for PLWHA; improving supplies, distribution, and usage in different guidelines on treatment, medication, supports, and counseling; health care facilities, treatment, and laboratory for STD, HIV, and AIDS cases; improving health care infrastructure, VCT services, PMTCT services, PLWHA treatment and people and family-based treatment, plus the support to form friendship with PLWHA; carrying out Metadhon Therapy Program; improving PLWHA access to health services; building visitation clinic for PLWHA, VCT test, and CD4 test, lessening community negative stigma towards PLWHA.

Agistin (2013) mentioned that there are a lot factors inhibiting HIV/AIDS countermeasure by KPA that is the problems on human resources and limited budget and facilities and infrastucture communication and information for
HIV/AIDS are inaccessible thus it would not help improving the knowledge. Other factors that may also affecting is the lack of in the PLWHA involvement in the policy or program.

The result of the study fit the available theory because Regional AIDS Countermeasure Commission Surakarta had given their emotional support, appreciation, social integrity, and informative support, however, PLWHA did not get enough of material/instrumental support. The said clinical approach could actually reduce the suffering because of HIV/AIDS and forestall further HIV infection, improving the quality of life PLWHA, lessening social impact and economy towards the individual, family, and community (KPAN, 2003; Saputri, 2015).

\section{7. the effect of perceived behavioral control towards HIV/AIDS countermeasure behavior}

Path analysis result in the study showed that perceived behavioural control had positive indirect relation towards HIV/ AIDS countermeasure behavior, although statistically insignificant. Perceived behavioral control is a one's perception about the ease and difficulty in carrying a certain behaviour (Ajzen, 1991). One's level of perception could also be used to predict one's behavior where the better one's perceived behavioral control, the higher the intention to carry out a behavior, until finally giving the effect on their behavior.

The above theory is in accordance with the study whereas PLWHA felt the difficultyu in preventing HIV/AIDS based on GIPA principles. PLWHA felt difficulty in becoming the speaker, practitioner, experts and decision makers. This could also be interpreted as becoming the speakers regarding HIV/AIDS in HIV/ AIDS related programs. PLWHA also felt that it was not easy to be the maker 
Adita et al./ Path Analysis on the Factors Affecting People's Behavior in HIV/AIDS Countermeasure

decision, policies, involved as planner, compliance, program evaluator/ organization in HIV/AIDS countermeasure and they felt difficulty in training their PLWHA friends to keep using ARV (antiretroviral) medicine, PLWHA care, ARV medicine effect, and the ways to prevent spreading HIV/AIDS. This was all because PLWHA was not sure on their own ability because they had never done this before and they lacked of time/chance in carrying out HIV/AIDS countermeasure behavior.

The study is in accordance with the study done by Fathimah (2014), that most of the parents/guardian found barriers in feeding nutritious food to HIV infected children. All subjects in the study had their own different difficulties, from the guardian, children with HIV infection, or facilities. The presence of power that facilitated or interfered one's conduct to carry out certain behavior. Some parents/guardian of children with HIV infection have strong preceived behavioral control towards the obstacles faced in giving nutritious food to the children. However the child's psychology did not always support the nutritious feeding behaviour, thus making it difficult for the parents/guardian to maintain the behaviour. Ajzen (2005) mentioned that perception on the behavioral control affects the intention based on the assumption that behavioral control perceived by an individual will imply on the person's motivation.

There is direct and positive relation on perceived behavioral control, Regional AIDS Countermeasure Commission support, peer support, health worker support, intention towards HIV/AIDS countermeasure behavior. There is indirect and positive relation among peer support, attitude, perceived behavioral control, family support towards HIV/AIDS countermeasure behavior.

\section{BIBLIOGRAPHY}

Agistin W (2013). Peranan Komisi Penanggulangan AIDS (KPA) dalam Penanggulangan HIV/ AIDS di Kota Samarinda. eJournal Ilmu Pemerintahan 1(4): 1434-1443.

Aisyah S (2012). Faktor- Faktor yang Berhubungan dengan Perilaku terhadap HIV/AIDS pada Siswa SMK Nusantara 01 Ciputat Kota Tangerang Selatan Tahun 2012. Jakarta: Skripsi. Fakultas Kesehatan Masyarakat Universitas Muhammadiyah Jakarta.

Ajzen (1991). The Theory of Planned Behavior. Organizational Behavior and Human Decision Processes 5O(2): 179-211.

Ajzen (2005). Attitudes, Personality and Behavior. England: Open University Press.

Alamo S, Wabwire MF, Kenneth E, Sunday P, Laga M, Colebunders RL (2012). Task-Shifting to Community Health Workers: Evaluation of The Performance of A Peer-Led Model in an Antiretroviral Program in Uganda. AIDS Patient Care STDs 26(2):101107.

Apondi R, Bunnell R, Awor A,Wamai N, Bikaako KW, Solberg P (2007). Home-Based Antiretroviral Care Is Associated with Positive Social Outcomes in A Prospective Cohort in Uganda. $J$ Acquir Immune Defic Syndr 44(1):71-76.

Arem H, Nakyanjo N, Kagaayi J, Mulamba J, Nakigozi G, Serwadda D (2011). Peer Health Workers and AIDS Care in Rakai, Uganda: A Mixed Methods Operations Research Evaluation of A Cluster-Randomized Trial. AIDS Patient Care STD 25(12):719-724. 
Azwar (2011). Sikap Manusia dan Pengukurannya. Yogyakarta: Pustaka pelajar.

Buse K, Jay J, Odetoyinbo M (2016). AIDS and Universal Health Coverage-Stronger Together. The Lancet Global Health 4(1): e10-e11.

Chang LW, Kagaayi J, Nakigozi G, Sempijja V, Packer AH, Serwadda D (2010). Effect of Peer Health Workers On AIDS Care in Rakai, Uganda: a clusterrandomized trial. PloS One 5(6): e10923.

Cooke R, Dahdah M, Norman P, French DP (2014). How Well Does The Theory of Planned Behaviour Predict Alcohol Consumption? A Systematic Review and Meta-Analysis. Health Psychology Review 10(2):148-167.

Diatmi K, Fridari IGAD (2014). Hubungan Antara Dukungan Sosial dengan Kualitas Hidup pada Orang Dengan HIV dan AIDS (ODHA) di Yayasan Spirit Paramacitta. Jurnal Psikologi Udayana 1(2): 353-362.

Fathimah F (2014). Gambaran Perilaku Orang Tua/Pengasuh dalam Memberikan makanan Bergizi kepada Anak Terinfeksi Human Immunodeficiency Virus di Yayasan Tegak Tegar Wilayah Jakarta Timur Tahun 2013. Skripsi. Universitas Islam Negeri Syarif Hidayatullah Jakarta.

Fishbein M, Ajzen I (1975). Belief, Attitude, Intention, and Behavior: An Introduction to Theory and Research. Reading, MA: Addison-Wesley.

Grimwood A, Fatti G, Mothibi E, Malahlela M, Shea J, Eley B (2012). Community Adherence Support Improves Programme Retention In Children On Antiretroviral Treatment: A Multicentre Cohort Study in South Africa. J Int AIDS Soc 15(2):17381.

Gustya RP, Farlinaa M, Alfitrib (2015). Studi Fenomenologi Pengalaman Orang HIV/AIDS (ODHA) dalam Mendapat- kan Dukungan Keluarga di Yayasan Lantera Minangkabau Support Padang. Ners Jurnal Keperawatan 11(1): 22-31.

Ignatavicius DD, Workman ML (2010). Medical Surgical-Nursing PatientCentered Collaborative Care.6th edition. St. Louis: Sounders Elsevier.

Igumbor JO, Scheepers E, Ebrahim R, Jason A, Grimwood A (2011). An Evaluation of the Impact of A Community-Based Adherence Support Programme on ART Outcomes in Selected Government HIV Treatment Sites in South Africa. AIDS Care 23(2):231236.

Johnson BA, Khanna SK (2004). Community Health Workers and HomeBased Care Programs for HIV Clients. J Natl Med Assoc 96(4):496-502.

Joseph JK, Rigodon J, Cancedda C, Haidar M, Lesia N, Ramanagoela L (2012). Lay Health Workers and HIV Care in Rural Lesotho: A Report from The Field. AIDS Patient Care STDs 26(3): 141-147.

Kementrian Kesehatan RI (2014). Infodatin. Pusat Data dan Informasi Kementrian Kesehatan RI. Situasi dan Analisis HIV AIDS. Jakarta Selatan: Kementrian Kesehatan RI.

Kipp W, Konde LJ, Rubaale T, Okech OJ, Alibhai A, Saunders DL (2011). Comparing Antiretroviral Treatment Outcomes Between a Prospective Community-Based and Hospital-Based Cohort Of HIV Patients in Rural Uganda. BMC Int Health Hum Rights 11(2):S12-S18.

Kipp W, Konde-Lule J, Saunders LD, Alibhai A, Houston S, Rubaale T (2011). Antiretroviral Treatment for HIV in Rural Uganda: Two-Year Treatment comes of a Prospective Health Centre/Community-Based and 
Adita et al./ Path Analysis on the Factors Affecting People's Behavior in HIV/AIDS Countermeasure

Hospital-Based Cohort. PloS one 7(7): e402-409.

Komisi Penanggulangan AIDS Daerah Surakarta (2016). Kasus Juni 2016, Laporan Kasus HIV AIDS di Solo Raya. KPAD Surakarta.

Komisi Penanggulangan AIDS Nasional (2003). Strategi Nasional Penanggulangan HIV/AIDS 2003 - 2007. Kementrian Koordinator Bidang Kesejahteraan Rakyat.

Kresno SB (2010). Imunologi: Diagnosis dan Prosedur Laboratorium. Edisi Kelima. Jakarta: Badan Penerbit Fakultas Kedokteran Universitas Indonesia.

Kusuma H (2011). Hubungan antara Depresi dan Dukungan Keluarga dengan Kualitas Hidup Pasien HIV/ AIDS yang Menjalani Perawatan di RSUPN Mangunkusumo Jakarta. Tesis. FIK UI.

Merken L, Candel M, Osch LV, Vries HD (2011). Smoke Without Fire: The Impact of Future Friends on Adolescent Smoking Behavior. British Journal of Health Psychology 16: 170-188.

Mwai GW, Mburu G, Torpey K, Frost P, Ford N, dan Seeley S (2013). Role and Outcomes of Community Health Workers in HIV Care in Sub-Saharan Africa: a Systematic Review. J Int AIDS Soc 16(1): 1-14.

Priyoto (2014). Teori Sikap dan Perilaku dalam Kesehatan. Yogyakarta: Nuha Medika.

Rich ML, Miller AC, Niyigena P, Franke MF, Niyonzima JB, Socci A (2012). Excellent Clinical Outcomes and High Retention in Care among Adults in a Community-Based HIV Treatment Program in Rural Rwanda. J Acquir Immune Defic Syndr 59(3):e35-e42.

Rosita R, Suswardani DL, Abidin Z (2012). Penentu Keberhasilan Berhenti Mero- kok pada Mahasiswa. KEMAS 8(1): 19.

Saputri L (2015). Peran Komisi Penanggulangan Aids (KPA) dalam Pencegahan dan Penanggulangan HIV dan AIDS di Kota Samarinda. eJournal Administrasi Negara 3(4):1280-1294.

Selke HM, Kimaiyo S, Sidle JE, Vedanthan R, Tierney WM, Shen C (2010). TaskShifting Of Antiretroviral Delivery From Health Care Workers To Persons Living with HIV/AIDS: clinical outcomes of a Community-Based Program in Kenya. J Acquir Immune Defic Syndr 55(4):483-490.

Simon S, Chu K, Frieden M, Candrinho B, Ford N, Schneider H (2009). An integrated approach of community health worker support for HIV/AIDS and TB care in Angonia district, Mozambique. BMC Int Health Hum Rights 9:13-20.

Smith BN, Bean MK, Michell KS, Speizer IS, Fries EA (2007). Psychosocial Factors Associated with Non Smoking Adolescents' Intentions to Smoke. Health Education Research 22 (2): 238247.

Spiritia (2011). Laporan Akhir Penelitian Peran Dukungan Sebaya terhadap Peningkatan Mutu Hidup ODHA di Indonesia Tahun 2011. Jakarta: Yayasan Spiritia.

Spritia (2003). Dari Prinsip ke Praktik. Keterlibatan Lebih Besar Orang yang Hidup dengan HIV/AIDS (GIPA). Seri Buku Kecil. Jakarta:Yayasan Spritia.

Thilakavathi S (2011). Assessment of The Scale, Coverage and Outcomes of the Avahan HIV Prevention Program for Female Sex Workers in Tamil Nadu, India: is there Evidence of an Effect?. BMC Public Health 11:S3-S6.

Thorhauge M, Haustein S, Cherchi E (2016). Accounting for the Theory of Planned Behaviour in Departure Time 
Choice. Transportation Research. Part F: Traffic Psychology and Behaviour (38): 94-105.

Tuapattinaja (2004). Gambaran dukungan sosial pada ODHA. Tesis. Fakultas Psikologi UI.

WHO (2016). Global Summary of The AIDS Epidemic 2015. Diakses pada http://www.who.int/hiv/data/epi_core_2 016.png?ua=1 tanggal 10-10-2016.

Wismanto YB, Sarwo YB (2006). Perilaku Merokok pada Karyawan Sekretariat Daerah Kabupaten/Kota di Jawa Te- ngah. Tesis. Semarang: Universitas Katolik Soegijapranata.

Yuswanto TJA, Wahyuni TD, Pitoyo J (2015). Peran Kelompok Dukungan Sebaya (KDS) dan Kepatuhan Minum Obat pada ODHA. Jurnal Pendidikan Kesehatan 4(1):64-69.

Zachariah R, Teck R, Buhendwa L (2007). Community support is associated with better antiretroviral treatment outcomes in a resource-limited rural district in Malawi. Trans R Soc Trop Med Hyg 101(1):79-84. 